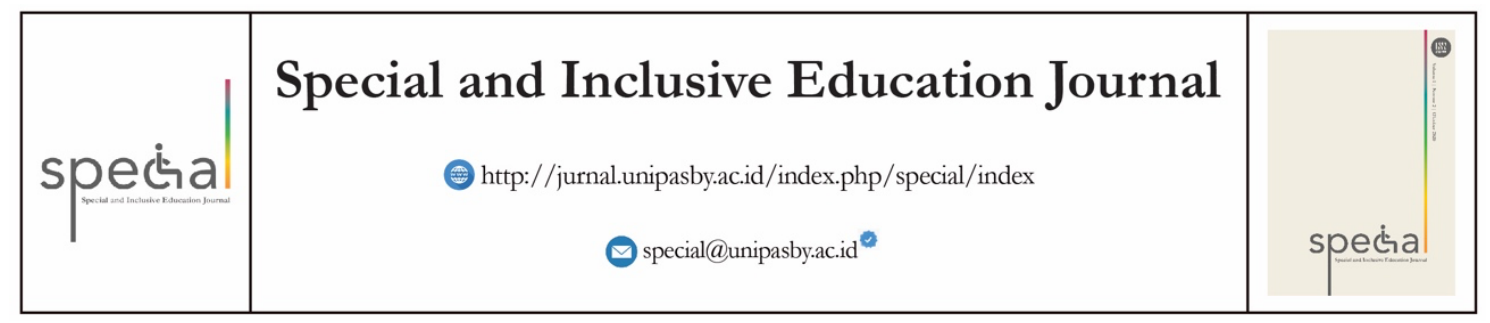

\title{
Pengembangan Bahan Ajar Tema Selalu Hemat Energi Berbasis E-Learning Untuk Peningkatan Hasil Belajar Siswa Tunarungu
}

\author{
Eko Julianto Wibowo \\ ekojuliantow@gmail.com
}

Sekolah Luar Biasa Negeri 1 Blitar

Jl. Cibareno No.39, Bendo, Kec. Kepanjenkidul, Kota Blitar, Jawa Timur 66116

\section{Artikel Info \\ Koresponden penulis : Eko Julianto Wibowo \\ ekojuliantow@gmail.com}

- Diterima 20 Oktober 2020

- Direview 31 Oktober 2020

- Disetujui 31 Oktober 2020

- Dipublikasi 31 Oktober 2020

Kata Kunci:

E-Learning, Hasil Belajar, Tunarungu

Keywords:

E-Learning, Learning

Outcomes, Deaf

\begin{abstract}
Absstrak
Tujuan penelitian ini untuk mengembangkan bahan ajar tema selalu hemat energi berbasis e-learning siswa tunarungu kelas VII. Penelitian ini pengembangan dengan menerapkan model Gall, Gall \& Borg (2003). Dilaksanakan dalam 10 tahapan: 1). identifikasi instruksional, 2). analisis intruksional, 3). mengidentifikasi karakteristik awal pebelajar, 4). instruksional khusus, 5). tes acuan patokan, 6). strategi instruksional khusus, 7). mengembangkan bahan ajar, 8). menyelenggarakan evaluasi formatif, 9). revisi instruksional, dan 10). desain dan evaluasi sumatif. Pengumpulan data dilakukan dengan kuesioner, evaluasi siswa, pretes dan posttes. Data dianalisis dengan deskriftif kualitatif, deskriftif kuantitatif dan analisis statistik uji-t dengan menggunakan aplikasi SPSS 17. Hasil review dari ahli isi materi menyatakan bahwa isi produk sangat baik, dari ahli Pendidikan Luar Biasa siswa tunarungu sangat baik, ahli media pembelajaran adalah baik. Hasil uji kelompok kecil adalah sangat baik dan hasil penilaian uji lapangan adalah sangat baik. Hasil uji-t dengan menggunakan aplikasi_SPSS 17 pada taraf signifikasi 5\% menunjukkan pretes 41,66 dan posttes 85,09 , sehingga Ho ditolak, dengan kata lain terdapat perbedaan yang signifikan hasil belajar siswa antara sebelum dan sesudah penggunaan bahan ajar berbasis elearning pada pembelajaran terpadu dengan tema selalu hemat energi.

Abstarct
The purpose of this study was to develop energy-efficient theme teaching
materials based on e-learning for deaf grade VII students. This research
was developed by applying the Gall, Gall \& Borg (2003) model.
Implemented in 10 stages: 1$)$. instructional identification, 2). instructional
analysis, 3). identify the initial characteristics of learners, 4). special
instructional, 5). benchmark reference test, 6). specific instructional
strategies, 7). developing teaching materials, 8). conduct formative
evaluation, 9). instructional revision, and 10). summative design and
evaluation. The data were collected by means of a questionnaire, student
evaluation, pretest and posttest. Data were analyzed using qualitative
descriptive, quantitative descriptive and t-test statistical analysis using the
SPSS 17 application. The results of the review from material content
experts stated that the product content was very good, from special
education experts for deaf students who were very good, learning media
experts were good. The results of the small group test were very good and
the results of the field test assessments were very good. The results of the
t-test using the SPSS 17 application at the $5 \%$ significance level showed a
pretest 41.66 and a posttest 85.09 , so that Ho was rejected, in other words
there was a significant difference in student learning outcomes between
before and after the use of elearning-based teaching materials in learning.
integrated with the theme of always energy saving.
\end{abstract}




\section{PENDAHULUAN}

Materi IPA tentang energi merupakan salah satu materi yang sangat penting karena hampir pada setiap pokok bahasan IPA membahas tentang energi. Pada pokok bahasan listrik terdapat sub pokok bahasan energi listrik. Begitu juga pada pokok bahasan mekanika, gelombang, dan optik terdapat sub pokok bahasan tentang energi yang secara prosedural. Sehingga dikenal berbagai macam bentuk energi, seperti energi listrik, energi panas, energi cahaya, dan lain sebaginya. Dalam kehidupan seharihari baik manusia, hewan, maupun tumbuhan memerlukan energi untuk melakukan aktivitasnya. Demikian juga dengan berbagai jenis mesin, mesin baru dapat berfungsi jika ada energi untuk menggerakkannya. Energi yang digunakan oleh manusia, hewan, dan tumbuhan berasal dari berbagai makanan dan minuman yang dikonsumsinya. Sementara energi yang digunakan mesin mobil berasal dari bahan bakar berupa bensin, solar, atau dapat juga berasal dari bahan bakar bentuk lainnya.

Pengertian energi menurut beberapa ahli Campbell, Reece, dan Mitchell (1996), menurut mereka energi ialah sebuah kemampuan untuk mengatur ulang materi. Dengan kata lain mereka mengartika energi sebagai kemampuan atau kapasitas untuk melakukan sebuah pekerjaan. energi merupakan sesuatu yang amat dibutuhkan oleh tubuh manusia supaya dapat melakukan suatu pekerjaan bisnis, karena pada kenyataannya, usaha yang dilakukan selalu nampak perubahan. Pada dasarnya energi dipakai untuk melakukan suatu pekerjaan Untuk menghasilkan suatu usaha juga dibutuhkan energi. Begitu pentingnya energi dalam kehidupan makhluk hidup, terutama manusia yang mampu meningkatkan teknologi yang menopang kehidupannya dengan memanfaatkan energi. Lebih lanjut tentang energi, energi memiliki berbagai bentuk yang dapat berubah. Perubahan-perubahan energi inilah yang sangat berguna bagi seluruh makhluk hidup. Sebagai manusia, tentunya kita dapat mengamati adanya perubahan-perubahan energi yang terjadi dalam keseharian kita meski tak dapat mengamati energi secara langsung.

Energi tentunya begitu berpengaruh pada setiap aspek kehidupan. Kita dapat melihat televisi didalam ruangan berlampu terang, itu merupakan salah satu konsep penerapan energi. Perubahan bentuknya dari listrik menjadi cahaya memudahkan hidup kita. Kita bisa menjalankan motor untuk pergi ke suatu tempat, itu juga penerapan energi. Dalam berbagai hal dan aspek tertentu, energi sudah jelas menjadi unsur tak bisa ditinggalkan manusia selama hidupnya. Dengan memahami pengertian energi di atas, kita dapat mengamati secara langsung berbagai hal yang menerapkan konsep energi pada kehidupan sehari-hari kita. Terkadang, tanpa kita sadari energi telah memudahkan kita melakukan pekerjaan apa saja dalam rutinitas hidup kita. Begitu mudahnya energi dipahami, sayangnya bentuk dari energi itu sendiri abstrak. Salah satu mata pelajaran yang membutuhkan pengalaman secara nyata adalah IPA dimana siswa diajak lebih dekat dalam kehidupan sehari-hari. Mata pelajaran IPA tidak terlepas dari tuntutan kurikulum dan merupakan salah satu mata pelajaran yang wajib dipelajari di sekolah. IPA bukan hanya penguasaan kumpulan pengetahuan yang berupa fakta-fakta, konsep-konsep atau prinsip-prinsip saja tetapi juga merupakan suatu proses penemuan. Pendidikan IPA diharapkan dapat menjadi wahana bagi peserta didik untuk mempelajari diri sendiri dan lingkungan sekitar, serta prospek pengembangan lebih lanjut dalam menerapkannya di dalam 
kehidupan sehari-hari. Proses ketercapaian pembelajaran IPA kelas VII siswa tunarungu menekankan pada pemberian pengalaman langsung untuk mengembangkan kompetensi agar siswa dapat membedakan macam-macam sumber energi dan manfaatnya.

Dari hasil observasi dilapangan terdapat kendala dalam pelaksanaan pembelajaran IPA materi sumber energi pada jenjang SMP kelas VII siswa tunarungu di beberapa sekolah yang dipelajari tidak maksimal dan seringkali belum tuntas pembahasan materinya waktunya sudah habis, dan siswa belum bisa mengerjakan tugas tanpa campur tangan dan bimbingan dari guru. Hal ini terjadi karena sebagian siswa kurang paham mengidentifikasikan sumber-sunber energi (panas, listrik, cahaya dan bumi) yang ada di lingkungan sekitar. Siswa juga lemah pada pelajaran Matematika materi penambahan, pengurangan, dan perkalian serta pada pelajaran Bahasa Indonesia materi mengamati, mengolah, dan menyajikan teks laporan hasil pengamatan tentang gaya, gerak, energi panas, bunyi, dan cahaya dalam bahasa Indonesia lisan dan tulis dengan memilih dan memilah kosakata baku.

Adanya kesulitan dalam mengidentifikasi dan menggolongkan jenis-jenis sumber energi tersebut, tentunya membuat siswa bingung atau belum bisa mengambil intisari untuk dipergunakan sebagai bahan dalam menjelaskan cara penggunaan masing-masing jenis sumber energi tersebut dengan baik. Adanya kesulitan yang dihadapi siswa tersebut berdampak pada hasil belajar tidak dapat dicapai secara optimal. Pembelajaran terpadu merupakan suatu pendekatan dalam pembelajaran yang secara sengaja mengaitkan beberapa aspek baik dalam intra mata pelajaran maupun antar mata pelajaran. Dengan adanya pemaduan itu, siswa akan memperoleh pengetahuan dan keterampilan secara utuh, sehingga pembelajaran menjadi bermakna bagi siswa. Bermakna disini memberikan arti bahwa pada pembelajaran terpadu siswa akan dapat memahami konsep-konsep yang mereka pelajari melalui pengalaman langsung dan nyata yang menghubungkan antar konsep dalam intra mata pelajaran maupun antar mata pelajaran. Saat ini menggunakan kurikulum 13 (K13) yang mengintegrasikan berbagai kompetensi dasar dari berbagai mata pelajaran ke dalam berbagai tema yang menekankan lebih kepada pembentukan karakter. Kementerian Pendidikan dan Kebudayaan 2014. Selanjutnya pembelajaran IPA materi sumber energi dikemas terpadu dengan mata pelajaran lain yaitu Matematika, Bahasa Indonesia dan Dasar Prakarya suatu usaha untuk mengintegrasikan pengetahuan, keterampilan, nilai, atau sikap pembelajaran, serta pemikiran yang kreatif dengan menggunakan tema selalu hemat energi.

Bagi anak normal, mendapatkan informasi dan wawasan bukanlah hal yang sulit, tetapi tidak bagi anak yang menderita ketunarunguan, mengingat anak tunarungu adalah anak yang mengalami kekurangan atau kehilangan kemampuan mendengar baik sebagian atau seluruhnya yang berakibat karena tidak berfungsinya sebagian atau seluruhnya alat pendengaran sehingga menghambat perkembangan intelegensi, bahasa, emosi dan sosialnya. (Somad dan Hernawati, 1995:27). Oleh sebab itu anak tunarungu lebih cenderung mengalihkan pengamatannya melalui indera visual. Inovasi dalam teknologi pembelajaran tidak pernah berhenti Anggrellanggi, dkk (2020). Teknologi yang terlibat dalam bidang ini selalu mencoba untuk mengembangkan penemuannya untuk meningkatkan kualitas pendidikan. salah satu inovasi yang sedang dikembangkan pada saat ini adalah inovasi penggunaan 
teknologi informasi untuk mendukung pembelajaran dalam bentuk e-learning. Penggunaan e-learning sebagai pembelajaran dapat diaplikasikan pada semua jenjang pendidikan dan keilmuan, tidak terkecuali pembelajaran terpadu.

E-learning merupakan kependekan dari elektronik learning. secara generik e-learning berarti belajar dengan menggunakan elektronik. Kata elektronik sendiri mengandung pengertian yang spesifik yakni belajar yang menggunakan komputer, smartphone atau internet. Dengan demikian elearning atau pembelajaran berbasis elektronik adalah pembelajaran yang memanfaatkan penggunaan teknologi informasi dalam bidang pembelajaran. Dalam penelitian ini pendekatan yang digunakan diharapkan dapat menempatkan pebelajar sebagai pusat perhatian (student centered) dan peran pembelajar sebagai fasilitator dalam mengupayakan bahan dan situasi untuk memperkaya pengalaman belajar pebelajar. Inovasi tersebut berupa pengembangan bahan ajar berbasis e-learning dengan aplikasi weblog pada pembelajaran terpadu di beberapa sekolah pada jenjang SMP kelas VII siswa Tunarungu.

\section{METODE PENELITIAN}

Penelitian ini menggunakan model pengembangan Meredith Gall, Joyce P.Gall dan Walter R. Borg yang sudah mengadaptasi tahapan model Dick and Carey. Secara lengkap, pendekatan penelitian dan pengembangan model ini mencakup 10 langkah umum yakni: 1) Identifikasi kebutuhan instruksional. 2) Melakukan analisis intruksional. 3) Mengidentifikasi perilaku dan karakteristik awal pebelajar. 4) Merumuskan tujuan instruksional khusus (TIK). 5) Menyusun tes acuan patokan. 6) Mengembangkan strategi instruksional khusus. 7) Mengembangkan bahan ajar. 8) Mendesain dan menyelenggarakan evaluasi formatif. 9) Merevisi instruksional yang telah dilakukan. dan 10) Mendesain dan melakukan evaluasi sumatif.

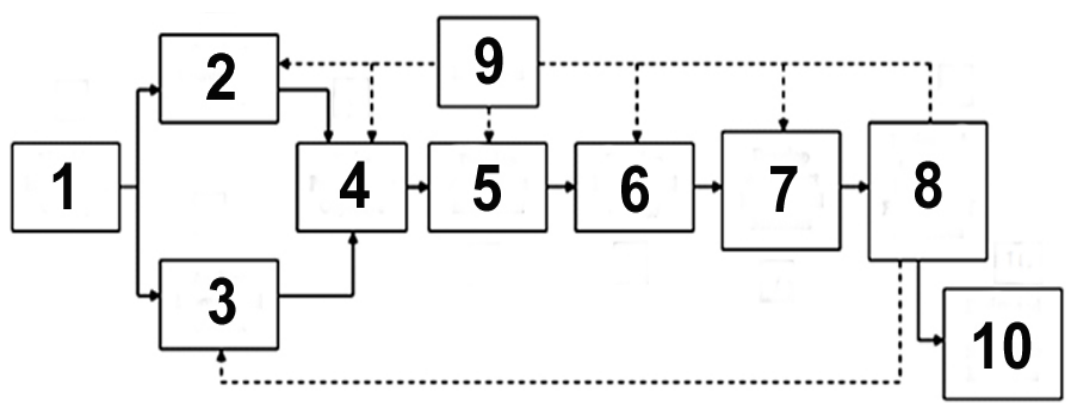

Gambar 1. 10 langkah model dari Meredith Gall, Joyce P.Gall dan Walter ( 2003)

Teknik analisis ini digunakan untuk mengolah data yang diperoleh melalui angket dalam bentuk deskriptif persentase. Rumus yang digunakan untuk menghitung persentase dari masing-masing subyek adalah sebagai berikut: 


$$
P=\frac{\sum x i}{\sum \mathrm{x}} \times 100 \%
$$

Keterangan :

$\mathrm{P} \quad=$ presentase penilaian

$\sum \mathrm{xi}=$ jumlah jawaban dari validator

$\sum \mathrm{x}=$ jumlah jawaban tertinggi

Selanjutnya untuk menghitung presentase keseluruhan subyek / komponen digunakan rumus sebagai berikut :

$P=\frac{\sum p}{\sum \mathbf{n}} \times 100$

Keterangan :

$\mathrm{P}=$ presentase keseluruhan subyek / komponen

$\sum \mathrm{p}=$ jumlah presentase keseluruhan komponen

$\sum \mathrm{n}=$ banyaknya komponen

Teknik analisis data deskriptif juga digunakan untuk mengolah data berupa hasil pretes dan posttes sehingga diketahui tingkat keefektifan produk pengembangan yang dihasilkan. Hasil pretes dan posttes diolah menggunakan uji-t dengan taraf signifikasi $5 \%(\alpha=0,05)$. Hipotesis kerja penelitian untuk diuji adalah sebagai berikut. Ho: tidak terdapat perbedaan prestasi belajar pembelajaran terpadu SMP kelas VII siswa tunarungu, setelah menggunakan media pembelajaran online e-learning dan sebelum menggunakan media pembelajaran online e-learning. Analisis statistik dengan bantuan perangkat lunak SPSS 17 dapat juga dilihat hasil uji Paired Samples Statistics untuk melihat jumlah sampel, nilai rata-rata (mean) dan standar deviasinya. Uji Paired Samples Correlations untuk menganalisis signifikasi korelasi atara pretes dan posttes.

\section{HASIL DAN PEMBAHASAN}

Hasil review isi materi produk yang dikembangakan sudah sesuai dengan kurikulum. Produk kualifikasi sangat baik dengan skor 97,05\%. Hasil review isi bahan ajar pada ahli Pendidikan Luar Biasa Produk kualifikasi sangat baik dengan skor $92,16 \%$. Hasil review media pembelajaran produk kualifikasi baik dengan skor 73,33\%. Hasil uji lapangan adalah sebagai berikut: 1) uji kelompok kecil, dilaksanakan pada SMP kelas VII siswa tunarungu di SLBN 4 Kota Blitar sebanyak 5 siswa. Hasil analisis angket kelompok kecil dengan skor penilaian $81 \%$ kualifikasi sangat baik. 2) uji lapangan, dilaksanakan pada SLBN 1 Kota Blitar 3 siswa, SLB Karya Mulia Surabaya 20 siswa, SLB Dewi Sartika Sidoarjo 4 siswa dan SLB-B Sananwetan Blitar 5 siswa dengan total keseluruhan 32 siswa. Hasil analisis angket online dengan skor penilaian $82 \%$ kualifikasi sangat baik. Tahap selanjutnya Mengembangkan bahan ajar diawali dengan mempersiapkan Naskah atau membuat konsep bahan ajar untuk diunggah alau diposting ke dalam blog. yang terdiri dari 1) bahan ajar, 2) 
Lembar Kerja Siswa (LKS) dan Lembar Evaluasi Siswa, mempersiapkan Attachment (gambar). Setelah seluruh naskah sudah terkumpul, dan gambar-gambar yang akan di posting sudah siap, maka semua bahan ajar bisa diunggah (upload) dalam blog yang telah didesain terlebih dahulu, memilih tempat penyedia blog. Dalam hal ini yang dipilih adalah wordpress. dan memperkaya bahan ajar dengan menghubungkan ke link-link lain yang dapat menunjang pembahasan materi pembelajaran. Desain pengembangan bahan ajar berbasis e-learning yang utuh :

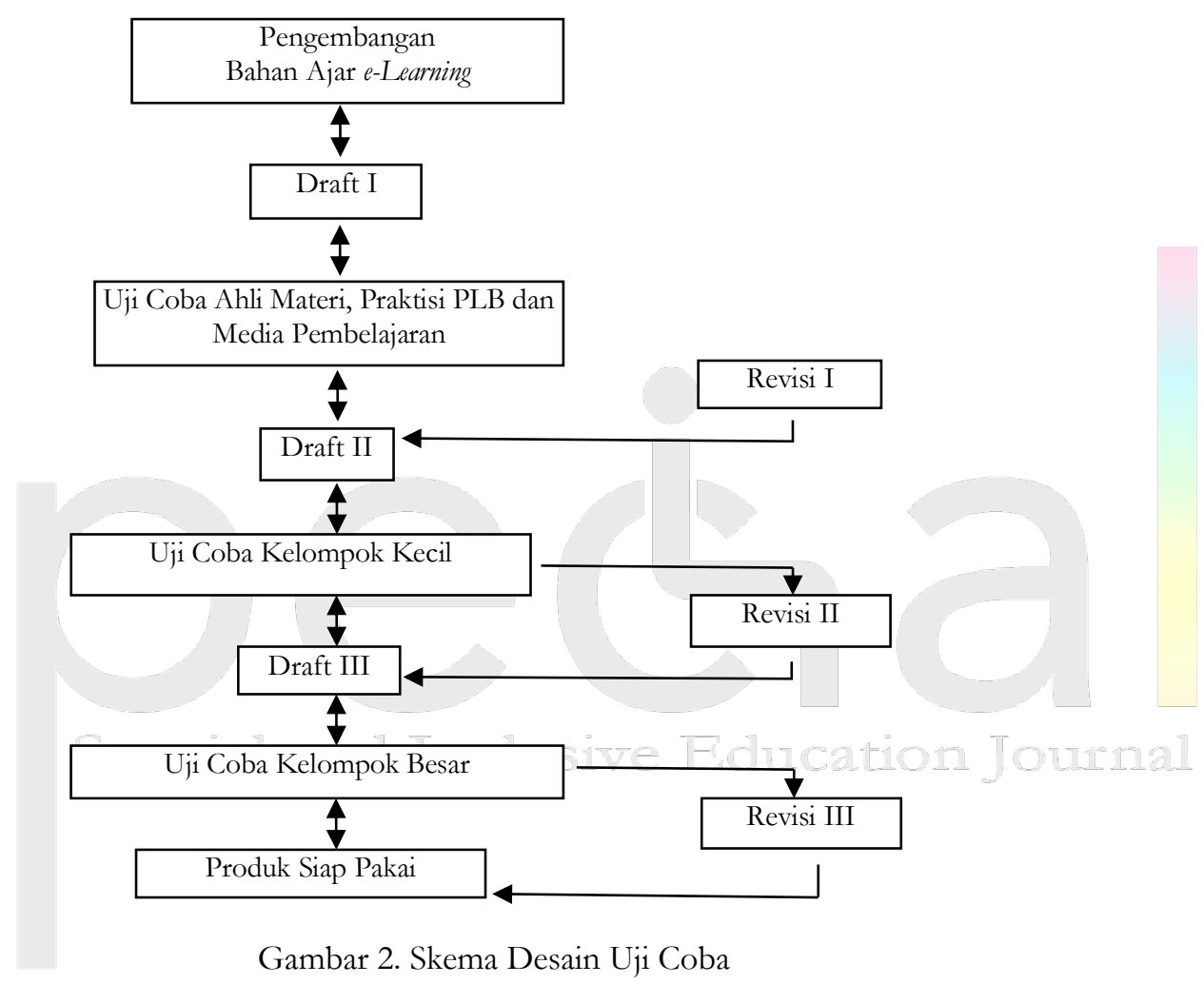

Uji ahli isi materi kepada Prof. Dr. Sri Poedjiastoeti, M.Si. Beliau adalah Dosen Pascasarjana Universitas Negeri Surabaya Program Studi Sains, Uji ahli praktisi Pendidikan Luar Biasa siswa tunarungu kepada Dra. Endang Purbaningrum, M.Kes Beliau adalah Dosen Universitas Negeri Surabaya Pendidikan Luar Biasa. sedangkan uji ahli media pembelajaran kepada Prof. Dr. Mustaji, M.Pd, profesi beliau adalah dosen di Pascasarjana Universitas Negeri Surabaya Program Studi Tekhnologi Pendidikan. Pengujian produk di lapangan dilakukan melalui uji coba secara terbatas/uji kelompok kecil di SMP kelas VII siswa tunarungu SLBN 4 Kota Blitar sebanyak 5 siswa. di sekolah yang memiliki jaringan internet wifi dan siswa terbiasa mengoprasikan komputer, laptop, notebook atau smartphone. Uji coba lapangan/uji kelompok besar di beberapa SMP kelas VII siswa tunarungu : SLBN 1 Kota Blitar 3 siswa, SLB Karya Mulia Surabaya 20 siswa, SLB Dewi Sartika Sidoarjo 4 siswa dan SLB-B Sananwetan Blitar 5 siswa dengan total keseluruhan 32 siswa, tentunya di sekolah yang memiliki jaringan internet wifi dan siswa terbiasa mengoprasikan komputer, laptop, notebook atau smartphone. Evaluasi formatif meliputi uji ahli isi materi, uji ahli media pembelajaran, uji coba secara terbatas/ uji coba kelompok kecil, dan uji coba lapangan. Data yang diperoleh dari masing- 
masing kegiatan uji coba tersebut dianalisis dan hasil analisis digunakan merevisi atau menyempurnakan produk pengembangan.
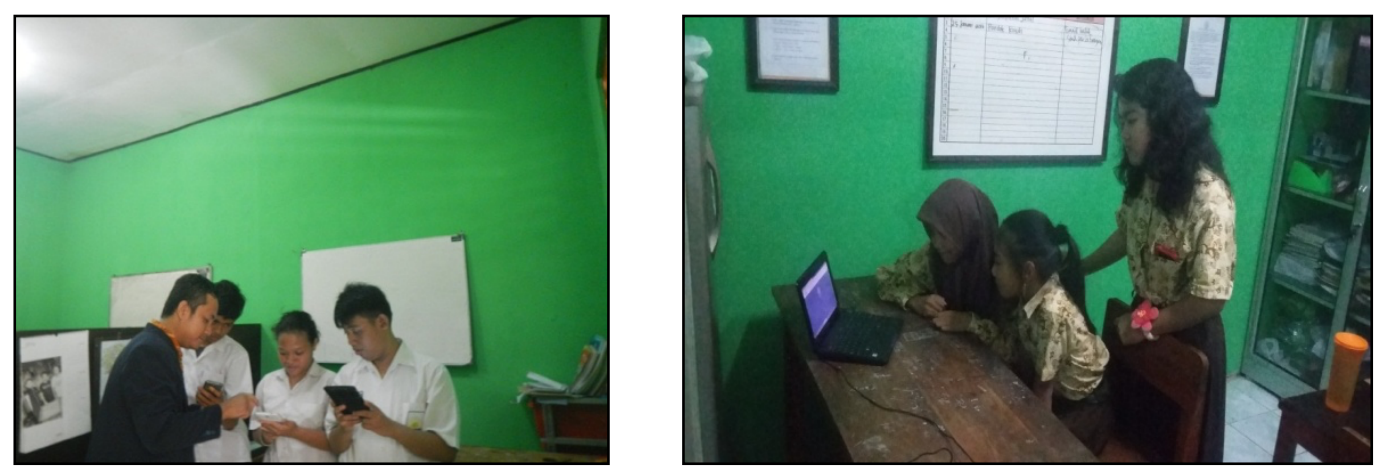

Gambar 3. Pelaksanaan Pembelajaran E-learning

Hasil uji statistik dengan prangkat lunak SPSS 17, Uji skala besar nilai rata-rata pretes 41,66 dan posttes 85,09. Uji Statistik dilakukan pada taraf signifikasi 5\%, sehingga Ho ditolak, dengan kata lain terdapat perbedaan yang signifikan hasil belajar siswa antara sebelum dan sesudah penggunaan bahan ajar elearning. Simpulannya adalah bahan ajar elearning berpengaruh positif dan signifikan terhadap penguasaan pengetahuan dalam pembelajaran terpadu dengan tema selalu hemat energi. Hasil penelitian menunjukkan bahwa, terdapat perbedaan yang signifikan hasil belajar siswa antara sebelum dan sesudah penggunaan bahan ajar elearning Badiah, L. I., Jauhari, M. N., \& Mambela, S. (2020). Ada beberapa hasil penelitian yang mendukung penelitian ini. Drigas, A.S (2005), masalah penelitian yakni platform e-learning sudah berubah tidak sesuai dengan kebutuhan, kegunaan dan kemampuan beradaptasi siswa berkebutuhan khusus tuli. sehingga siswa terasa kesulitan dalam mengakses e-learning. Hasil penelitian ini menyediakan informasi bilingual (teks dan bahasa isyarat), visualisasi tingkat tinggi dan belajar dengan teman-teman melalui video. Khwaldeh, S (2007), masalah penelitian yakni pedoman yang sudah ada tidak sesuai dengan usia dan menyebabkan kesulitan bagi anak-anak untuk berinteraksi dengan teman-temannyaHasil penelitian menyediakan pedoman program e-learning untuk anak-anak tunarungu berusia antara 7-13 tahun, dan pada webnya ada pemberian informasi suara juga disajikan bersama dalam video.

\section{KESIMPULAN}

Berdasarkan Analisis data dan pembahasan penelitian ini, maka dapat disimpulkan sebagai berikut: 1) Produk yang dihasilkan berupa bahan ajar online dapat terselesaikan sesuai. Produk yang diimplementasikan dapat berjalan baik pada komputer, laptop, notebook dan smartphone dengan jaringan internet wifi, modem atau paketan simcard internet. Bahan ajar ini dapat diakses lebih luas tidak terbatas jarak dan waktu, bisa diakses lewat warnet atau mobile technology berbasis smart. (smartphone, iphone, ipad, tab, dan gadget lainnya). 2) Uji validasi dapat berjalan sesuai rencana dan lancar. Hasil review dari ahli isi materi menyatakan bahwa isi produk sudah sesuai dengan kurikulum. 
Hasil tanggapan sangat baik dengan skor 97,05\%. Hasil review isi bahan ajar pada ahli Pendidikan Luar Biasa Produk kualifikasi sangat baik dengan skor 92,16\%. Hasil review media pembelajaran produk kualifikasi baik dengan skor 73,33\%. Hasil uji kelompok kecil sangat baik dengan skor 81\%. Hasil penilaian uji lapangan sangat baik dengan skor $82 \%$. 3) Efektifitas dan signifikasi bahan ajar berbasis elearning terhadap hasil belajar setelah dilakukan analisis data pretes dan protes menunjukan sebagai berikut. Hasil analisis uji Paired Samples Test dengan prangkat lunak SPSS 17, Uji skala besar nilai rata-rata pretes 41,66 dan posttes 85,09. Uji Statistik dilakukan pada taraf signifikasi 5\%, sehingga $\mathrm{H} 0$ ditolak, dengan kata lain terdapat perbedaan yang signifikan hasil belajar siswa antara sebelum dan sesudah penggunaan bahan ajar elearning. Simpulannya adalah bahan ajar elearning berpengaruh positif dan signifikan terhadap penguasaan pengetahuan dalam pembelajaran terpadu dengan tema selalu hemat energi.

\section{DAFTAR PUSTAKA}

Anggrellanggi, A., Supratiwi, M., Yusuf, M., \& Martika, T. (2020). Penguatan Aksesibilitas Model Blended Learning pada Matakuliah Bahasa Indonesia bagi Mahasiswa Tunarungu dan Tunanetra. SPECLAL: Special and Inclusive Education Journal, 1(1), 25-30.

Badiah, L. I., Jauhari, M. N., \& Mambela, S. (2020). Penerapan Pelatihan Terapi Auditory Verbal Therapy (AVT) untuk Mengembangkan Kemampuan Bahasa Anak Tunarungu. Jurnal ORTOPEDAGOGLA, 6(1), 39-42.

Drigas, A., Kouremenos, S., Vrettos, S., Vrettaros, J., \& Kouremenos, D., 2004, An Expert System For Job Matching Of The Unemployed. Expert Systems with Applications, 26, 217-224.

Campbell, N. A., Jane, B. R., Lawrence, G. M. alih bahasa Rahayu Lestari, et al. 2008. Biologi. Biologi Edisi Kedelapan Jilid I. Jakarta: Erlangga.

Dick, W. \& Carey, L. 2001. The Systemic Design of Instruction. Fifth Edition. USA; Harper Collin Publisher

Meredith Gall, Joyce P Gall \& Walter R. Walter. (2003). Educational Research An introduction, Seventh Edition. Pearson Education, Inc.

Permanarian Somad dan Tati Hernawati. 1995. Ortopedagogik Anak Tunarungu. Bandung: Departemen Pendidikan dan Kebudayaan.

Khwaldeh, S., Matar, N., \& Hunaiti, Z. (2007). Interactivity in deaf classroom using centralised Elearning system in Jordan. PGNet, ISBN, 1-9025. 